\title{
OBSTACLES OF COMMUNITY-BASED TOURISM DEVELOPMENT IN VUKOVAR-SRIJEM COUNTY
}

\author{
Vanja Krajinović \\ Danijela Ferjanić Hodak \\ Antonio Vlahov
}

https://doi.org/10.20867/tosee.05.12

\begin{abstract}
Purpose - Purpose of the paper is to determine and analyze obstacles of tourism development in Vukovar-Srijem County. The main focus of this paper is put on analyzing obstacles of tourism development in the County by using the theoretical knowledge about community-based tourism. One of the key objectives is to emphasize the importance of local community in the process of creating tourism product, as they are affected by it either directly or indirectly.

Methodology - A desk research method is used for creation of theoretical framework and identification of key obstacles to community-based tourism development. For the purpose of primary research, a deeply structured online questionnaire was created. The main objective of the survey is to identify the level of awareness about tourism development benefits among local residents included in tourism offer.

Findings - Based on the conducted research, it is possible to conclude that there is still not enough cooperation between public and private sector within this area. Additionally, authors identify main challenges and provide recommendations for the future tourism development in Vukovar-Srijem County.

Contribution - This paper provides thorough theoretical overview of the tourism development theory, with special emphasis on community-based tourism as one of the key potentials in Vukovar-Srijem County. Primary research provides insight into current state of awareness of local service providers about potentials of tourism development within their area, but more importantly, about key obstacles they are faced with. By combining theoretical and empirical conclusions, authors provide recommendations for future improvements.

Keywords community-based tourism, obstacles of tourism development, local community, developing region, Vukovar-Srijem County
\end{abstract}

\section{INTRODUCTION}

Tourism development in its core has to be directed towards improving the local community's quality of life. However, contemporary changes in global economy and distribution of power make it difficult for developing countries to take over significant role in decision-making process at destination level. "Most developing destinations and microstates lack significant amounts of wealth and political power, which makes them prone to decision-making that is completely beyond their control"' (Timothy, 2002, 149). Due to its main objectives, community-based tourism development is closely related to sustainable tourism development concept, with strong intention to include local community's interests into development policies and to minimize leakages out of the economy as much as possible. Since the Brundtland Report it has become evident that sustainable tourism development has to be built upon the ideas and postulate of 
ToSEE - Tourism in Southern and Eastern Europe, Vol. 5, pp. 389-403, 2019

V. Krajinović, D. Ferjanić Hodak, A. Vlahov: OBSTACLES OF COMMUNITY-BASED TOURISM ...

partnership building and collaboration (Okazaki, 2008, 514). In order to elaborate the main purpose of this paper, it is necessary to define the meaning of the term "community", as it "may be geographical in nature or a community of interest, built on heritage and cultural values hared among community members" (Joppe, 1996, 475). The same author claims that community and municipality is not always a synonymous. For the purpose of this paper, a community is delineated as a county, more specifically, Vukovar-Srijem County. It is located at the far east of the Republic of Croatia and is dealing with numerous challenges, mostly arising from the fact that after the Homeland War this area had to recover and rebuilt most of its infrastructure, help people to return after being refugees for several years, improve the quality of life, but most importantly, this area had to deal with human suffering and partake in creating positive living atmosphere. All these factors have had significant impact on developing Vukovar-Srijem County during the last 20 years and the effects of that development are analyzed in this paper, especially in relation to tourism development.

Community-based development in general is "concerned with the involvement of local stakeholders in decision-making" (Narayan, 1995, 5). Mansuri and Rao claim that "community-based development is an umbrella term for projects that actively include beneficiaries in their design and management" $(2004,1)$. Community involvement is a concept of high importance, but there are many potential traps in which policy makers might get caught if they not get fully aware of all potentials and disadvantages of community-based development in general, tourism development in particular. These characteristics are elaborated in the paper and, based on the conducted primary research, the current situation with community-based tourism development in Vukovar-Srijem County is analyzed. The main research question is: What are the main obstacles of community-based tourism development in Vukovar-Srijem County and what could be done in order to overcome those obstacles?

\section{THEORETICAL REVIEW}

Numerous benefits of community-based development in general can be emphasized. "Community-based management on a large scale requires fundamental changes in the policies, incentives, and structures of agencies" (Narayan, 1995, 6-7). Even though the main idea of this concept is poverty alleviation, improving socio-economic well-being and empowering local government, there are some evidence that this approach does very little for the poorest members of the society (e.g. Park and Wang, 2010; Baldwin et al., 2016). Based on their research results it is not possible to argue that community-based programs have helped in alleviating poverty within these villages. "The two words, 'local' and 'participation', are regularly used together to emphasise the need to include and involve local people; and it is this juxtaposition of the two words which implies, paradoxically, that it is local people who have so often been left out of the planning, decision-making and operation of tourist schemes" (Mowforth and Munt, 2003, 212). Even though it would be reasonable to expect that local interests are managed by local stakeholders, in majority of destinations this is not the case. Such situation does not necessarily have to be related to local political situation, it could be that local government has to follow national policies which are not always adjusted to local specifics and therefore cannot yield optimal results for the local community. Community-based 
ToSEE - Tourism in Southern and Eastern Europe, Vol. 5, pp. 389-403, 2019

V. Krajinović, D. Ferjanić Hodak, A. Vlahov: OBSTACLES OF COMMUNITY-BASED TOURISM ...

tourism has therefore been extensively researched and has remained in the focus of different researchers in terms of identifying specific benefits and opportunities for the local communities (Álvarez-Garcia, Durán-Sánchez and De la Cruz Del Río-Raman, 2018; Del Chiapa, Atzeni and Ghasemi, 2018; Dodds and Glaski, 2018; Mayaka, Croy and Wolfram Cox, 2018; Hung Lee and Jan, 2019).

Community-based tourism development can be defined as "an ecosystem approach, where visitors interact with local living (hosts, services) and non-living (landscape, sunshine) to experience a tourism product" (Murphy, 1985 in Jamal and Getz, 1995, 188). Another definition by International Labour Organisation (2005 in Zapata et al., $2011,727)$ states that "community-based tourism is any business organizational form grounded on the property and self management of the community's patrimonial assets, according to democratic and solidarity practices; and on the distribution of the benefits generated by the supply of tourist services, with the aim at supporting intercultural quality meetings with the visitors". In such environment local stakeholders manage all resources within a destination and all actions have to be undertaken in the best interest of local community. "Community development has proven to be especially effective in responding to the needs of disadvantaged populations and marginalized communities by creating jobs and improving their social circumstances" (Joppe, 1996, 476). In that sense, it could easily be concluded that tourism development based on community's long-term needs would be a significant incentive for improving the quality of life within that area and including all of its potentials into creation of more stimulative environment. However, the aforementioned studies do not support these objectives nor the ideas that lie in the core of community-based development. "Without measuring the net benefits of the community-based tourism initiative, income less the capital and recurrent costs, it is not possible to determine whether the community and individual households have benefited or been impoverished by the intervention" (Goodwin and Santilli, 2009). If every action and process within a destination was as easily established, contemporary tourism development would be rather sustainable and without reproaches. The real situation is, sadly, somewhat different. "The destination domain is characterized by an open-system of interdependent, multiple stakeholders, where the actions of one stakeholder impact on the resto of the actors in the community" (Jamal and Getz, 1995, 193). In such idealistic environment, all stakeholders would have equal opportunity to maximize their own potentials and interests, but the main issue with this concept is the question of power. Regardless of destination's size, this question is almost always present. If stakeholders are given the right to make decisions at destination level, implement created strategies and develop destination upon those policies, then community-based development makes sense and can be expected to improve the quality of life within that community. Otherwise, its potentials and objectives might be considered as questionable and politicized. "While community-based tourism is intended to empower people, the representations deployed in constituting the targeted 'communities', be they imagined or real, remain largely unexamined" (Salazar, 2012, 9).

"Community tourism analysts tend to assume, often implicitly, that the planning and policy process is a pluralistic one in which people have equal access to economic and political resources" (Reed, 1997, 567). This approach, however, is another example of often idealistic reasoning of relationships within destination and distribution of resources and power at any level, either local, regional, national or international. "Changing the 
ToSEE - Tourism in Southern and Eastern Europe, Vol. 5, pp. 389-403, 2019

V. Krajinović, D. Ferjanić Hodak, A. Vlahov: OBSTACLES OF COMMUNITY-BASED TOURISM ...

nature and physical face of a destination, as well as the overall type of experience offered, may and often does involve the destination departing more and more from its original characteristics, and quite probably moving further and further from sustainability" (Butler, 1997, 109). It is very often the case that destinations think of economic benefits only in the short-run. Community-based tourism should overcome downsides arising from former unsustainable development. That development should be directed towards long-term preservation of destination's capital, whatever it might be. In that sense communities would be given a means for implementing policies that enable socioeconomic well-being for future generations as well. Host communities should be given a voice in the process of shaping their future community as their right and they should have maximum involvement in order to maximize socio-economic benefits of tourism (Inskeep, 1991 in Tosun, 2000, 616). "This community development explicitly seeks to dismantle structural barriers to participation and develop emancipatory collective responses to local issues" (Blackstock, 2005, 40). Raising the awareness and consolidating the interests at destination level enables stakeholders to be empowered in the sense that they have clear vision about what they wish to achieve and how they want their tourism development to be managed. This task leads to another major issue, which is related to defining the existing level of community participation. In the end, the success relies on the collaboration and understanding between all stakeholders involved in the process.

Even though the question of community, as argued, is not strictly defined nor geographically determined, during 1970s community-based tourism assumed small communities. "Community is a very illusive and vague term. It is used to refer not only a locality (e.g. a village community) but also a network of relationships (e.g. cyberspace communities)" (Salazar, 2012, 10). Albeit at the beginning most programmes were related to small rural communities and nature conservation through ecotourism, the concept has been extended to a range of different tourism products and managerial models around the world (Zapata et al., 2011, 726). Indeed, tourism development has enabled communities to embrace the potentials of improving local economic environment, preserving resources and enriching socio-cultural interactions. "Communities are increasingly being drawn into tourism not only from the demand side, as tourists actively seek out new destinations and communities to experience, but also from the supply side, as communities are becoming aware of the potential of the products they can offer to tourists and the economic gains that can be made" (Telfer and Sharpley, 2008, 115). Narayan identified three factors that influence the prospect of communitybased development, as not every situation is appropriate for that strategy. Those factors are the nature of the good or service, the nature of benefits and the nature of the task $(1995,7)$.

In order to determine potentials of community-based tourism development in VukovarSrijem County, the authors decided to adopt an approach of determining its obstacles. The goal is to examine whether those obstacles are soluble and if they thereby enable more intensive tourism development in the County. "While the goals of communitybased tourism are commendable and worthwhile to pursue, and their contributions to sustainable development are obvious, many barriers to their operationalization exist; this is particularly the case in the less developed world" (Timothy, 2002, 159). The same author (Timothy, 2002, 159-163) has identified obstacles analyzed in this paper, and they 
ToSEE - Tourism in Southern and Eastern Europe, Vol. 5, pp. 389-403, 2019

V. Krajinović, D. Ferjanić Hodak, A. Vlahov: OBSTACLES OF COMMUNITY-BASED TOURISM ...

are power: socio-political traditions, gender and ethnicity, information accessibility, lack of awareness, economic issues, lack of cooperation/partnership and peripherality.

The question of gender and ethnicity is extremely important in the process of tourism development. These two groups have not been justly involved in the decision-making process during past. "This treatment has its roots in the socio-political traditions, for most power structures are patriarchal, operating at the exclusion of women and minorities" (Timothy, 2002, 160). This is usually related to the question of traditional jobs, extended family and economic development of the area. Numerous authors have referred to the question of gender of tourism development, stressing the importance of empowering women (e.g. Byrne Swain, 1995; Kinnaird and Hall, 1996; Wall, 1997; Ferguson, 2011). The issue of ethnicity has also been researched, dominantly through the perspective of ethnic tourism (e.g. Wood, 1984; Hitchcock, 1999; Jamison, 1999; Yang and Wall, 2009; Yang, 2011). For instance, Jamison concludes that many ethnic tensions within destinations are the result of close economic interdependence among ethnic groups combined with fierce competition over available and potential resources $(1999,963)$. Even though ethnic diversity and gender equality should add to the overall quality of life and economic prosperity within community, not always is this the case.

One presumption of the community-based tourism development is intensive cooperation among all stakeholders. Therefore, the level of awareness is of crucial importance in the process of implementation, as the lack of knowledge will lead to resilience towards the concept and, consequently, potentially to its failure. Inadequate local expertise results in a lack of proper training among tourism officials, which represents an important barrier to allowing community input into the process (Timothy, 2002, 161). The results of primary research indicate that there is strong connection between the level of tourism development in the County and awareness about the potentials of community-based development. Hence, some of the examinees state that the level of specialized education is too low, that there is not a clear vision about the area development, that the amount of financial support for local businesses is insufficient, entrepreneurial climate is highly disincentive and that joint programs are necessary. It could be concluded that the level of awareness of local stakeholders is rather high, while national and local development policies do not support their initiative for more intensive community-based tourism development. Additionally, there are some economic issues, such as lack of education, social status or family connections, which have to be taken into consideration when discussing the possibilities for locals to be involved in community-based tourism development. Additionally, low socio-economic status also represents a limitation for active involvement in tourism decision-making process. Peripheral position of tourism areas has been researched extensively (e.g. Keller, 1984; Keller, 1987; Weaver, 1998; Kneafsey, 2000; Hospers, 2003) and all studies have reached similar conclusions that the question of peripherality is related to the issue of center-periphery conflicts. According to Keller (1987), lack of local manpower and expertise in tourism is identified as the major block to successful development of a locally controlled industry. This situation is strongly related to the question of orientation towards community-based tourism development. In such situation, all decisions would be made locally and the issue of geographical position would be less important, hence, peripheral location would be irrelevant. 
ToSEE - Tourism in Southern and Eastern Europe, Vol. 5, pp. 389-403, 2019

V. Krajinović, D. Ferjanić Hodak, A. Vlahov: OBSTACLES OF COMMUNITY-BASED TOURISM ...

Based on these findings, it is possible to conclude that community-based tourism development is facing numerous challenges, mostly arising from operational perspective and the fact that it is not easy to determine limits of community involvement at any level. Moreover, local interests are not easily balanced and managed. Most importantly, that question is more often than not a political issue, which complicates relationships and disrupts the distribution of power. Due to all these reasons, community-based tourism is not always as successful concept as it is expected to be and is shows certain limitations when incorporated into destination's development policies. If managed properly, however, it can bring numerous potential gains into the community and some of them are: the allocation of development funds more responsive to the needs of the local community, improving the targeting of poverty program, making government more responsive, improving the delivery of public goods and services and strengthening the capabilities of the citizenry to undertake self-initiated development activities (Mansuri and Rao, 2004, 2). These potentials and obstacles are analyzed on the example of Vukovar-Srijem County in the Republic of Croatia.

\section{SPECIFIC FEATURES OF VUKOVAR-SRIJEM COUNTY}

Vukovar-Srijem County is located at the far east of the Republic of Croatia, between rivers Danube and Sava and covers the area of $2448 \mathrm{~km}^{2}$ (Vukovar-Srijem County, n.d.). It boarders with the Republic of Serbia on the east and Bosnia and Herzegovina on the south. Among the main reasons for choosing this county for the purpose of primary research are its enormous tourism potentials that have not been reached yet. It is in the focus of this research to identify reasons for such situation. Furthermore, due to rural attributes of this county, community-based tourism development has significant potentials. "Attitudes toward tourism have often been conducted in rural communities as many of these places struggle with economic viability" (Andereck and Vogt, 2000, 28). Economic situation in this county is not favorable and therefore the aim is to examine whether community-based tourism can be considered as a tool for overcoming economic problems. Historically, this county has always been on the crossroad of many cultural and economic circulations, which has added to its diversity on one side, but also to its complexity on the other side. Somewhere in the middle of all problems that occupy this county and its inhabitants lies substantial tourism potential, in desperate need of stakeholder cooperation. Community-based tourism development might be a potential for overcoming all accumulated problems and enabling more intensive involvement on tourism market.

If we analyze Vukovar-Srijem County in terms of its stage of development, it can be argued that it is yet in its initial stage. As Epler Wood has summed up: emerging tourism destinations are yet being discovered; do not have large investment in local tourism infrastructure; there is a high level of informality in tourism offerings and low number of visitors who are discovering the area compared with the number of residents; and local residents are generally welcoming to the visitors and sill living a life that is similar to before tourism arrived $(2017,267)$. This stage assumes significant efforts of all stakeholders involved in the process, as this is a point where strategies and policies have to be defined, but at the same time, it enables creation of more sustainable, communitybased policies that will be beneficiary for future generations as well. Therefore, the more 
ToSEE - Tourism in Southern and Eastern Europe, Vol. 5, pp. 389-403, 2019

V. Krajinović, D. Ferjanić Hodak, A. Vlahov: OBSTACLES OF COMMUNITY-BASED TOURISM ...

intensive growth will be based upon well-though strategies that will be more effective in the long run.

According to CBS $(2013,2018)$ data, population in Vukovar-Srijem County is constantly decreasing. What is more, in 1991 Vukovar-Srijem County had the share of $4.8 \%$ of entire population of Croatia, while in 2017 it has decreased for $1 \%$. One of the reasons for such situation is the absence of business opportunities and extremely high unemployment rate (more than 20\%, according to CBS (2018)), which is one of the highest in Croatia. This forces young people to seek the opportunity for better quality of life in other parts of Croatia or abroad. According to CBS (2018), Vukovar-Srijem County has negative net migration, one of the highest in Croatia. In 2017, almost 7000 people left this area, while more than 1000 came to find their opportunity in the County. The community-based tourism development could be one of the tools for improving the migration balance in Vukovar-Srijem County. Besides the high unemployment rate, Vukovar-Srijem County has the third lowest GDP per capita in Croatia. GDP per capita in 2015 was 80,555 Croatian Kuna, while Vukovar-Srijem County had GDP per capita 47,446 Croatian Kuna (Croatian Chamber of Economy, 2018, 4). Based on these data, it can be concluded that local residents have many concerns related to their short-term quality of life, which does not leave them enough space to become involved in tourism decision-making. On the other hand, it is the core idea of community-based tourism development to provide opportunities for locals to launch their businesses and create positive living standards based on sustainable principles in the long run.

\section{METHODOLOGY}

Primary research was conducted during December 2018 and January 2019. The sampling frame for the primary research consisted of the business entities in Vukovar-Srijem County directly included in tourism offer (accommodation facilities, souvenir shops, museums, restaurants, family farms). Questionnaire consists of eight questions, seven with structured answers and one open question. Open question provided insight into opinion concerning necessary steps which should be taken by local authorities in order to improve community-based tourism by higher involvement of local entrepreneurs. The majority of the results is based on the question comprising 14 statements which were graded with the Likert scale (grades from 1 to 5). Statements provided answers necessary for the analyses of theoretical presumptions for community-based tourism development. Other questions provided information about age, gender, revenue, education, ethnicity and place of residence. The questionnaire was sent on 104 e-mail addresses. Return rate was almost $60 \%$ (60 valid questioners). The structure of examinees is as follows: $56.7 \%$ were female and average age was 47.4 years. More than half of them had high school degree $(53.3 \%)$, while the remaining $46.7 \%$ had higher education. Among the most important information gained through the research is that $93.3 \%$ of examinees were residents of Vukovar-Srijem County, while $10 \%$ belonged to a national minority. The data was analysed by using descriptive statistics methods, due to the sample size and the specifics that do not require inferential statistic methods. 
ToSEE - Tourism in Southern and Eastern Europe, Vol. 5, pp. 389-403, 2019

V. Krajinović, D. Ferjanić Hodak, A. Vlahov: OBSTACLES OF COMMUNITY-BASED TOURISM ...

\section{RESEARCH RESULTS}

Research results are elaborated based on the primary and secondary research conducted for the purpose of this paper. They are analysed based on the aforementioned elements defined by Timothy $(2002,159-163)$. In order to provide thorough insight in the research results, average grades and mode for each statement are listed in the Table 1.

Table 1: Opinion of business entities included in tourism offer concerning community-based tourism in Vukovar-Srijem County $(n=60)$

\begin{tabular}{|l|c|c|}
\hline \multicolumn{1}{|c|}{ Statements } & Aver. & Mode \\
\hline $\begin{array}{l}\text { Tourism development has positive impact on the quality of life of the local } \\
\text { population. }\end{array}$ & 4.47 & 5 \\
\hline $\begin{array}{l}\text { Local population has good knowledge on local tourism attractions in the } \\
\text { Vukovar-Srijem County. }\end{array}$ & 2.37 & 2 \\
\hline $\begin{array}{l}\text { County provides positive environment for development of entrepreneurial } \\
\text { activities. }\end{array}$ & 2.67 & 3 \\
\hline $\begin{array}{l}\text { Higher level of local population awareness about the importance of } \\
\text { tourism development would provide positive effect on the development of } \\
\text { tourism offer. }\end{array}$ & 4.4 & 5 \\
\hline $\begin{array}{l}\text { Amenable institutions educate local population about the importance of } \\
\text { tourism development in the County. }\end{array}$ & 2.27 & 3 \\
\hline Possibilities of economic supports in tourism are easily available. & 2.07 & 2 \\
\hline Service providers in tourism in the County have a good cooperation. & 2.77 & 3 \\
\hline Other service providers in tourism in the County are my competitors. & 2.4 & 3 \\
\hline I have all the knowledge necessary for providing tourism services. & 3.23 & 3 \\
\hline I use on-line distribution channels in my business activity. & 3.47 & 4 \\
\hline Tourist board of Vukovar-Srijem County has good promotional activities. & 2.97 & 3 \\
\hline I am actively involved in the promotional activities of tourist board. & 2.77 & 4 \\
\hline $\begin{array}{l}\text { My communication with the tourism demand is well covered with my } \\
\text { marketing activities. }\end{array}$ & 3.1 & 4 \\
\hline Other service providers in tourism in the County are considered partners. & 3.8 & 4 \\
\hline
\end{tabular}

Source: primary research

Statements outlined in Table 1 are analyzed through the theoretical presumptions for community-based tourism development.

\section{Power: Socio-political traditions}

The role of local authorities in the process of creating tourism product as well as in the development of certain areas (such as tourism destinations) is unmistakable. In Croatia, the power concentration in state authorities is still quite expressed. This situation is not encouraging for proactive local authorities due to their limited autonomy in resolving numerous issues. Vukovar-Srijem County, with its exceptional potential for tourism development, is faced with additional challenges when talking about local authorities, due to numerous disagreements between national groups in that area. Along with certain demographic issues and depopulation problem, especially in rural areas, local as well as state authorities need clear and unambiguous plan for encouraging culture of togetherness and mutual cooperation that is considered as postulate of successful and sustainable development in tourism. Conducted primary research regarding possibilities of local authorities in terms of encouraging stronger inclusion of small entrepreneurs in 
ToSEE - Tourism in Southern and Eastern Europe, Vol. 5, pp. 389-403, 2019

V. Krajinović, D. Ferjanić Hodak, A. Vlahov: OBSTACLES OF COMMUNITY-BASED TOURISM ...

tourism activities provides interesting answers. Firstly, local authorities are expected to encourage inclusion in specialized education programs for tourism, as well as being more active in promoting destination. Due to two most common answers, it can be concluded that entrepreneurs are already aware of how important it is to track and adjust to tourism trends. Financial subsidies are third most common answer. Small entrepreneurs in tourism can contribute to creation of innovative tourism products and can be considered as basis for sustainable tourism development in destination. Therefore, it is necessary to accept their requests and allow them stronger involvement in decision making process related to tourism policy in destination.

\section{Gender and ethnicity}

According to the CBS (2013) data, 51.71\% of inhabitants in the Vukovar-Srijem County in 2011 were female, while $20.83 \%$ of inhabitants belonged to one of 20 national minorities in the County. Such ethnic diversity represents a huge potential for creating variety of tourism products based on cultural heritage, especially on its intangible aspect. However, the Homeland War has disrupted relations between different national minorities within this County and disabled more intensive cooperation in the process of tourism product development. As the research results indicate that $56.7 \%$ of examinees were female, it could be concluded that gender disparity is not as present in the County as expected and that is not necessarily obstacle of tourism development. As for the question of minorities, since only $10 \%$ of examinees belonged to one of many minorities in the County, this is potentially an aspect that could be improved. The increase in the number of members of minorities would have twofold effects - it would strengthen the inclusion of those community members into creation of gross national product at county level, but even more, it would add to the diversity of tourism product at destination level. However, the conclusion in paper relate solely on the research sample and cannot be generalized for the entire County.

\section{Information accessibility}

When it comes to locally owned businesses, information accessibility is one of the obstacles of tourism development, especially on less developing markets. However, the organization in charge of helping small business to reach potential demand is Tourist Board. Tourist Board of the Vukovar-Srijem County, according to its financial plan and activities described on the official web page (Vukovar-Srijem Tourist Board, n.d.), helps small businesses to promote themselves not only on local, but also on the international level, which is confirmed by the results of the primary research. More than $70 \%$ of examinees said that they are satisfied with the actions of Tourist Board. Despite this fact, one of the main suggestions of the examinees was to put even more effort in promotional activities, since this is the best way to bring more tourist in the County, as well as to include more small business in local events. Examinees have stressed out the importance of networking between tourism providers, which can be improved by planned actions of Tourist Board, as well as the necessity of workshops that would enable locals to be informed about the possibilities and opportunities for inclusion in tourism supply. According to the research results, 33\% of examinees are actively included in Tourist Board's promotional activities. The inclusion of other tourism providers in the activities of Tourist Board could result not only with more tourists in the County, but also would provide a higher level of satisfaction for locals who have the opportunity the be active participants and decision makers. The primary research results also indicated that almost 
ToSEE - Tourism in Southern and Eastern Europe, Vol. 5, pp. 389-403, 2019

V. Krajinović, D. Ferjanić Hodak, A. Vlahov: OBSTACLES OF COMMUNITY-BASED TOURISM ...

$60 \%$ of examinees consider that they have good on-line communication with the demand side of the market. Due to these results, it is possible to conclude that information accessibility does not represent an obstacle for community-based tourism in VukovarSrijem County.

\section{Lack of awareness}

Local community is extremely important segment of this kind of development and therefore their lack of understanding about tourism can be a significant limiting factor. According to research results, $68.2 \%$ of examinees disagree with statement that local community is properly familiarized with tourism resources and attractions of VukovarSrijem County. At the same time, 55.2\% of them strongly agrees with the statement that higher level of local community's awareness about the importance of tourism would have positive effects on the development of tourism offer. These results confirm that the level of awareness of local stakeholders, excluding the local community, is rather high and they could create tourism product that would be competitive on tourism market and simultaneously create positive living environment. However, local community should be familiarized with this concept more intensively so that even those who are not directly involved in the creation of tourism product and yielding financial benefits out of it, could comprehend the positive impact of that development on local infrastructure and long term economic and demographic structure of the County.

\section{Lack of cooperation/partnerships}

Primary research has emphasized high level of awareness in terms of cooperation and alliance with the aim to establish better competitive position on the market. This finding encourages advocates of new cycle of tourism development in continental Croatia that should be predominately based on alliancing small entrepreneurs that protect local identity and tradition. Only $13 \%$ of examinees see mutual cooperation between providers of services in tourism as successful, which is sign that there is a need for stronger incentive for mutual cooperation between existing, but also necessity for inclusion of new business providers. It is obvious that existing providers of services in tourism are aware that without mutual cooperation further steps are not possible, because $53.3 \%$ of examinees do not see other providers of services as direct competition, while $70 \%$ see them as partners. One of the obstacles for stronger inclusion of local community of Vukovar-Srijem County in providing services in tourism is the lack of knowledge about tourism resources and attraction of that area. In fact, $63.3 \%$ of examinees believe that local inhabitants are not familiarized with the importance of resources sufficiently. Examinees evaluate extremely bad possibilities and ease of usage subsidies in tourism. This is an aspect on which local authorities have to put more active effort and give impulse in terms of educating and helping local people, especially in rural areas. Only $13.3 \%$ examinees see Vukovar-Srijem County as positive surrounding for development of entrepreneurship activities in tourism. However, at the end of 2018 five Slavonia Counties have signed cooperation agreement, which stands as basis for joint performances in terms of preparations and implementations of development projects that will enable stronger tourism development within this area (Osijek-Baranja County, 2018). Aspiration for mutual synergy of local institutions and organizations to higher levels of power should be definitely pointed out as a positive progress. 
ToSEE - Tourism in Southern and Eastern Europe, Vol. 5, pp. 389-403, 2019

V. Krajinović, D. Ferjanić Hodak, A. Vlahov: OBSTACLES OF COMMUNITY-BASED TOURISM ...

Economic issues and peripherality were analysed based on secondary data and were interpreted earlier in the paper.

\section{DISCUSSION AND POLICY RECOMMENDATIONS}

There is little doubt that community-based tourism, despite some of its imperfections, is extremely beneficial for destinations and its inhabitants. Problems with this development concept arise dominantly from inadequate implementation and insufficient knowledge about its benefits. The research conducted in this paper has emphasized certain problems related to recent tourism development in Vukovar-Srijem County. Based on those results, authors propose several recommendations for increasing the quality of community-based tourism development within this area.

There is a significant dissatisfaction with the level of education regarding this concept of tourism development. Stakeholders that were included in the research indicated that the level of specialized education is not satisfactory and that they would very much like to be engaged in more intensive education about the possibilities of accessing external sources of financing, dominantly EU funding. This would enable much larger number of stakeholders much easier business opportunities. Even though many stakeholders are aware of their importance in the process of creating tourism products, it is crucial to emphasize that their enthusiasm and expertise guarantee a successful development basis in the long run. However, it is even more important to educate local community about the benefits that they could yield through this development concept. The research results clearly emphasize that stakeholders do not perceive local community as supportive factor in the development process, especially because they cannot support authentic product to tourists, which is the final objective. That education should be an outcome of collaboration between private and public sector, as the benefits are mutual and the vision of development should be clearly defined and followed by related actions.

Basis for enabling sustainable tourism development can be found in creating competitive product and respecting the local heritage (both natural and man-made). Those two are closely related, as local heritage is one of the key presumptions of community-based tourism. Additionally, competitive product will enable awaking local pride that would consequently improve the quality of the product offered to tourists. As already mentioned, gastronomy and wine tourism have had significant importance in the creation of tourism product in this County. Based on that intangible heritage, it is possible to continue with creation of high quality rural product that would meet the needs of contemporary tourists that seek peaceful and picturesque areas for their holidays. What is more, if the quality of the product is high, it is more likely to attract tourists with higher ability to pay for this product. If the pressure of tourists on the area is not too high, principles of sustainable tourism can be balanced and the concept of tourism development can be considered as successful. 
ToSEE - Tourism in Southern and Eastern Europe, Vol. 5, pp. 389-403, 2019

V. Krajinović, D. Ferjanić Hodak, A. Vlahov: OBSTACLES OF COMMUNITY-BASED TOURISM ...

Due to the diversity of this County, authors stress additional recommendation for successful policy development, and it is to respect and encompass differences among local inhabitants, whatever they might be. The presence of 20 different national minorities forms enormous potential for creating diverging tourism product that would encompass cultural heritage and uniqueness of each minority.

All aforementioned can hardly be accomplished without the cooperation between local entrepreneurs and public sector. Since the power to make decisions lies on the side of public sector, positive attitude on both sides is of fundamental importance for successful collaboration. Empowering local entrepreneurs would enable their proactive participation in the decision-making process, while simultaneously local government would have the insight into obstacles that local entrepreneurs are faced with. Such collaboration is a basic presumption for successful implementation of community-based tourism development, as confirmed by numerous scientific research that has been consulted during this research. This recommendation, together with the increasing problem of insufficient education on all levels, represent starting point for improving the overall state of tourism offer in the Vukovar-Srijem County and to enable more intensive community-based tourism development and all benefits that it brings into a destination.

Based on the research results, it is possible to stress certain limitations of the conducted research. Firstly, one limitation was relatively short period during which the research was being carried out. It is possible to abstract two main recommendations for future research. It would be necessary to conduct in-depth interview with persons in charge of making decisions within a company or a public organization. This would provide much more information about the particular problems that stakeholders are faced with. Furthermore, additional value would be gained through including public sector and local community into the research, as their perspective could add another dimension into the process of solving the obstacles that prevent more intensive community-based tourism development within the area of Vukovar-Srijem County.

\section{CONCLUSION}

Community-based tourism development is not a newly created concept nor is it inherent for tourism only. Benefits that communities could gain are irrefutable, but at the same time poorly implemented objectives and inadequate cooperation between all stakeholders lead to the failure of the concept. Communities are put in the centre of this concept as the main idea is to respect its heritage, enable its preservation and long term exploitation that is based on the principles of sustainable tourism development. Additionally, the objective is to minimise leakages out of the economy and to thereby ensure regional development. Members of the community would have gains on different levels, depending on the intensity of their involvement in this process. It is possible to emphasize the possibilities of infrastructural improvements, increasing job opportunities, developing local products and strengthening local pride. The research conducted in Vukovar-Srijem County indicated that stakeholders that are members of supply side of the process are aware of the potentials that community-based tourism could provide. However, they are faced with inadequate support by the local community and local government and therefore this can be considered as insurmountable obstacle if it were 
ToSEE - Tourism in Southern and Eastern Europe, Vol. 5, pp. 389-403, 2019

V. Krajinović, D. Ferjanić Hodak, A. Vlahov: OBSTACLES OF COMMUNITY-BASED TOURISM

not dealt with in the short run. Tourism resources of this area are highly suitable for developing quality tourism products that would ensure economic stability in the long run, while simultaneously providing a framework for preserving identity of the local community.

\section{REFERENCES}

Álvarez-Garcia, J., Durán-Sánchez, A. and De la Cruz Del Río-Rama, M. (2018), "Scientific Coverage in Community-Based Tourism: Sustainable Tourism and Strategy for Social Development", Sustainability, Vol. 10, No. 4. doi: 10.3390/su10041158

Andereck, K.L. and Vogt, C.A. (2000), “The Relationship between Residents' Attitudes toward Tourism and Tourism Development Options", Journal of Travel Research, Vol. 39, August, pp. 27-36. doi: $10.1177 / 004728750003900104$

Baldwin, K., Karlan, D., Udr, C. and Appiah, E. (2016), "Does Community-Based Development Empower Citizens? Evidence from a Randomized Evaluation in Ghana", viewed 31 January 2019, https://www.poverty-action.org/publication/does-community-based-development-empowercitizens-evidence-randomized-evaluation-ghana

Blackstock, K. (2005), “A critical look at community based tourism”, Community Development Journal, Vol. 40, No. 1, pp. 39-49. doi: 10.1093/cdj/bsi005

Bramwell, B and Sharman, A. (2000), "Approaches to sustainable tourism planning and community participation: The case of the Hope Valley", in Richards, G. and Hall, D. (Eds.), Tourism and Sustainable Community Development, Routledge, New York, pp. 17-35.

Bulter, R. (1997), "Modeling Tourism Development", in Wahab, S. and Pigram, J.J. (Eds.), Tourism, Development and Growth, Routledge, New York, pp. 109-125.

Byrne Swain, M. (1995). "Gender in tourism”, Annals of Tourism Research, Vol. 22, No. 2, pp. 247-266. doi: 10.1016/0160-7383(94)00095-6

CBS (Croatian Bureau of Statistics) (2013), Popis stanovništva, kućanstava i stanova u Republici Hrvatskoj 2011. godine, viewed 4 February 2019, https://www.dzs.hr/

CBS (Croatian Bureau of Statistics) (2018), Statistički ljetopis, viewed 6 February 2019, https://www.dzs.hr/

Croatian Chamber of Economy (2018), BDP po županijama, viewed 8 February 2019. https://www.hgk.hr/documents/bdp-po-zupanijama-u-2015-godini-final25ad8955342dfa.pdf

Del Chiappa, G., Atzeni, M. and Ghasemi, V. (2018), "Community-based collaborative tourism planning in islands: A cluster analysis in the context of Costa Smeralda", Journal of Destination Marketing \& Management, Vol. 8, June, pp. 41-48. doi: 10.1016/j.jdmm.2016.10.005

Dodds, R., Ali, A. and Galaski, K. (2018), "Mobilizing knowledge: determining key elements for success and pitfalls in developing community-based tourism", Current Issues in Tourism, Vol. 21, No. 13, pp. 1547-1560. doi: 10.1080/13683500.2016.1150257

Epler Wood, M. (2017), Sustainable tourism on a finite planet, Routledge, New York.

Ferguson, L. (2011), "Promoting gender equality and empowering women? Tourism and the third Millennium Development Goal”, Current Issues in Tourism, Vol. 14, No. 3, pp. 235-249. doi: 10.1080/13683500.2011.555522

Goodwin, H. and Santilli, R. (2009), “Community-Based Tourism: a success?”, viewed 31 January 2019 https://www.researchgate.net/publication/265278848_CommunityBased_Tourism_a_success_Community-Based_Tourism_a_success

Hitchcock, M. (1999), "Tourism and ethnicity: situational perspectives", International Journal of Tourism Research, Vol. 1, No. 1, pp. 17-32.

Hospers, G.-J. (2003), "Localization in Europe's Periphery: Tourism Development in Sardinia", European Planning Studies, Vol. 11, No. 6, pp. 629-645. doi: 10.1080/0965431032000108369

Hung Lee, T. and Jan, F.-H. (2019), "Can community-based tourism contribute to sustainable development? Evidence from residents' perceptions of the sustainability", Tourism Management, Vol. 70, February, pp. 368-380. doi: 10.1016/j.tourman.2018.09.003

Jamal, T.B. and Getz, D. (1995), "Collaboration Theory and Community Tourism Planning", Annals of Tourism Research, Vol. 22, No. 1, pp. 186-204. doi: 10.1016/0160-7383(94)00067-3

Jamison, D. (1999), "Tourism and ethnicity: The brotherhood of coconuts", Annals of Tourism Research, Vol. 26, No. 4, pp. 944-967. doi: 10.1016/S0160-7383(99)00042-0

Joppe, M. (1996), "Sustainable community tourism development revisited", Tourism Management, Vol. 17, No. 7, pp. 475-479. doi: 10.1016/S0261-5177(96)00065-9 
ToSEE - Tourism in Southern and Eastern Europe, Vol. 5, pp. 389-403, 2019

V. Krajinović, D. Ferjanić Hodak, A. Vlahov: OBSTACLES OF COMMUNITY-BASED TOURISM ...

Keller, C.P. (1984), "Centre-periphery tourism development and control”, in Long, J. and Hecock, R. (Eds.), Leisure, Tourism and Social Change, Centre for Leisure Research, Edinburgh. pp. 77-84

Keller, C.P. (1987), "Stage of peripheral tourism development - Canada's northwest territories", Tourism Management, Vol. 8, No. 1, pp. 20-32. doi: 10.1016/0261-5177(87)90036-7

Kinnaird, V. and Hall, D. (1996), "Understanding tourism processes: a gender-aware framework", Tourism Management, Vol. 17, No. 2, pp. 95-102. doi: 10.1016/0261-5177(95)00112-3

Kneafsey, M. (2000), "Tourism, Place Identities and Social Relations in the European Rural Periphery", European Urban and Regional Studies, Vol. 7, No. 1, pp. 35-50. doi: $10.1177 / 096977640000700103$

Mansuri, G. and Rao, V. (2004). "Community-Based and -Driven Development: A Critical Review", The World Bank Research Observer, Vol. 19, No. 4, pp. 1-39. doi: 10.1090/wbro/lkh012

Mayaka, M., Croy, W.G. and Wolfram Cox, J. (2018), "Participation as motif in community-based tourism: a practice perspective", Journal of Sustainable Tourism, Vol. 26, No. 3, pp. 416-432. doi: $10.1080 / 09669582.2017 .1359278$

Merriam-Webster, n.d., Community, viewed 30 January 2019, https://www.merriam-webster.com/dictionary/community

Mowforth, M. and Munt, I. (2003), Tourism and Sustainability: Development and New Tourism in the Third World, Routledge, New York.

Narayan, D. (1995), Designing Community Based Development, The World Bank, Washington.

Okazaki, E. (2008), “A Community-Based Tourism Model: Its Conception and Use”, Journal of Sustainable Tourism, Vol. 16, No. 5, pp. 511-529. doi: 10.1080/09669580802159594

Osijek-Baranja County (2018), Cooperation Agreement, viewed 30 January 2019, http://www.obz.hr/hr/ images/zupanijski_glasnik/2018/sporazum_o_suradnji_zmedju_osjecko_baranjske_brodsko_posa vske_pozesko_slavonske viroviticko_podravske i_vukovarsko_srijemske zupanije.pdf

Park, A. and Wang, S. (2010), "Community-Based Development and poverty alleviation: An evaluation of China's poor village investment program", Journal of Public Economics, Vol. 94, No. 9-10, pp. 790-799. doi: 10.1016/j.jpubeco.2010.06.005

Reed, M.G. (1997), "Power relations and community-based tourism planning", Annals of Tourism Research, Vol. 24, No. 3, pp. 566-591. doi: 10.1016/S0160-7383(97)00023-6

Salazar, N.B. (2012), "Community-based cultural tourism: issues, threats and opportunities", Journal of Sustainable Tourism, Vol. 20, No. 1, pp. 9-22. doi: 10.1080/09669582.2011.596279

Telfer, D.J. and Sharpley, R. (2008), Tourism and Development in the Developing World, Routledge, New York.

Timothy, D.J. (2002), "Tourism and Community Development Issues", in Sharpley, R. and Telfer, D.J. (Eds.), Tourism and Development - Concepts and Issues, Channel View Publications, Clevedon, pp. 149164.

Tosun, C. (2000), "Limits to community participation in the tourism development process in developing countries", Tourism Management, Vol. 21, No. 6, pp. 613-633. doi: 10.1016/S0261-5177(00)00009-1

Vukovar-Srijem County, n.d., General Information, viewed 1 February 2019, http://www.vusz.hr/info/osnovni-podaci

Vukovar-Srijem Tourist Board, n.d., Propisi i dokumenti, viewed 3 February 2019, http://www.visitvukovarsrijem.com/hr/zakoni-i-propisi/

Wall, G. (1997), "Sustainable tourism - Unsustainable development", in Wahab, S. and Pigram, J.J. (Eds.), Tourism, Development and Growth, Routledge, New York, pp. 33-49.

Weaver, D.B. (1998), "Peripheries of the periphery: Tourism in Tobago and Barbuda", Annals of Tourism Research, Vol. 25, No. 2, pp. 292-313. doi: 10.1016/S0160-7383(97)000094-7

Wood, R.E. (1984), "Ethnic tourism, the state, and cultural change in Southeast Asia", Annals of Tourism Research, Vol. 11, No. 3, pp. 353-374. doi: 10.1016/0160-7383(84)90027-6

Yang, L. (2011), "Ethnic tourism and cultural representation", Annals of Tourism Research, Vol. 38, No. 2, pp. 561-585. doi: 10.1016/j.annals.2010.10.009

Yang, L. and Wall, G. (2009), "Minorities and tourism: community perspectives from Yunnan, China", Journal of Tourism and Cultural Exchange, Vol. 7, No. 2, pp. 77-98. doi: 10.1080/14766820902849971

Zapata, M.J., Hall, C.M., Lindo, P. and Vanderschaeghe, M. (2011) "Can community-based tourism contribute to development and poverty alleviation? Lessons from Nicaragua", Current Issues in Tourism, Vol. 14, No. 8, pp. 725-749. doi: 10.1080/13683500.2011.559200 
ToSEE - Tourism in Southern and Eastern Europe, Vol. 5, pp. 389-403, 2019

V. Krajinović, D. Ferjanić Hodak, A. Vlahov: OBSTACLES OF COMMUNITY-BASED TOURISM ...

Vanja Krajinović, $\mathrm{PhD}$, Assistant Professor

University of Zagreb, Faculty of Economics \& Business

Department of Tourism

Trg J.F. Kennedy 6, 10000 Zagreb, Croatia

Phone: +385-1-2383270

E-mail: vkrajinovic@efzg.hr

Danijela Ferjanić Hodak, PhD, Assistant Professor

University of Zagreb, Faculty of Economics \& Business

Department of Tourism

Trg J.F. Kennedy 6, 10000 Zagreb, Croatia

Phone: +385-1-2383269

E-mail: dferjanic@efzg.hr

Antonio Vlahov, $\mathrm{PhD}$, Assistant Professor

University of Zagreb, Faculty of Economics \& Business

Department of Tourism

Trg J.F. Kennedy 6, 10000 Zagreb, Croatia

Phone: +385-1-2383270

E-mail: avlahov@efzg.hr 